Prepared for the U.S. Department of Energy

under Contract DE-AC05-76RL01830

\title{
L-325 Sagebrush Habitat Mitigation Project: FY2009 Compensation Area Monitoring Report
}

Robin E. Durham

Michael R. Sackschewsky

September 2009

Pacific Northwest

NATIONAL LABORATORY 


\title{
DISCLAIMER
}

This report was prepared as an account of work sponsored by an agency of the United States Government. Neither the United States Government nor any agency thereof, nor Battelle Memorial Institute, nor any of their employees, makes any warranty, express or implied, or assumes any legal liability or responsibility for the accuracy, completeness, or usefulness of any information, apparatus, product, or process disclosed, or represents that its use would not infringe privately owned rights. Reference herein to any specific commercial product, process, or service by trade name, trademark, manufacturer, or otherwise does not necessarily constitute or imply its endorsement, recommendation, or favoring by the United States Government or any agency thereof, or Battelle Memorial Institute. The views and opinions of authors expressed herein do not necessarily state or reflect those of the United States Government or any agency thereof.

\author{
PACIFIC NORTHWEST NATIONAL LABORATORY \\ operated by \\ BATTELLE \\ for the \\ UNITED STATES DEPARTMENT OF ENERGY \\ under Contract DE-AC05-76RL01830
}

Printed in the United States of America

\author{
Available to DOE and DOE contractors from the \\ Office of Scientific and Technical Information, \\ P.O. Box 62, Oak Ridge, TN 37831-0062; \\ ph: (865) 576-8401 \\ fax: (865) $576-5728$ \\ email: reports@adonis.osti.gov
}

Available to the public from the National Technical Information Service,

U.S. Department of Commerce, 5285 Port Royal Rd., Springfield, VA 22161

ph: (800) 553-6847

fax: (703) 605-6900

email: orders@ntis.fedworld.gov

online ordering: http://www.ntis.gov/ordering.htm 


\section{L-325 Sagebrush Habitat Mitigation Project: FY2009 Compensation Area Monitoring Report}

Robin E. Durham

Michael R. Sackschewsky

September 2009

Prepared for

the U.S. Department of Energy

under Contract DE-AC05-76RL01830

Pacific Northwest National Laboratory

Richland, Washington 99352 



\section{Summary}

Annual monitoring in support of the Fluor Daniel Hanford Company (Fluor) Mitigation Action Plan (MAP) for Project L-325, Electrical Utility Upgrades was conducted in June 2009. MAP guidelines defined mitigation success for this project as 3000 established sagebrush transplants on a 4.5 ha mitigation site after five monitoring years. Annual monitoring results suggest that an estimated 2130 sagebrush transplants currently grow on the site. Additional activities in support of this project included gathering sagebrush seed and securing a local grower to produce between 2250 and 250010 -in ${ }^{3}$ tublings for outplanting during the early winter months of FY2010. If the minimum number of tublings grown for this planting meets quality specifications, and planting conditions are favorable, conservative survival estimates indicate the habitat mitigation goals outlined in the MAP will be met in FY2014. 



\subsection{Introduction}

This document provides a review and status of activities conducted in support of the Fluor Daniel Hanford Company (Fluor) Mitigation Action Plan (MAP) for Project L-325, Electrical Utility Upgrades (2007). Annual monitoring results will be presented for planting activities conducted in late February 2007 and early January 2008. A discussion will outline recommendations for the completion of DOE habitat mitigation commitments remaining for this project.

\subsection{Background}

Installation of the new $13.8 \mathrm{kV}$ electrical distribution line between the $251-\mathrm{W}$ substation and the $100 \mathrm{~K}$ area resulted in the loss of approximately 1.5 ha (3.7 acres) of mature sagebrush steppe. Hanford site biological resource management guidelines stipulate compensatory mitigation via habitat replacement for this level and type of disturbance (DOE 2001, 2003). A MAP was prepared to outline the measures necessary to mitigate these ecological resource losses (Fluor 2007).

Commitments outlined in the MAP provided for planting 5000 Wyoming big sagebrush (Artemisia tridentata ssp wyomingensis) transplants over a 4.5 hectare (11 acre) site. A planting of this nature would result in a shrub density of 1111 sagebrush transplants per hectare (450/acre) which is consistent with management guidelines (DOE 2001, 2003). The project mitigation site is located north of the B/C cutoff road, which is just west of the L-325 site of disturbance (Fig 1).

During the FY07 reporting period, 4 -in ${ }^{3}$ tublings were purchased and transplanted. When the tublings were delivered, some did not meet minimum quality specifications and were rejected. This shortfall resulted in planting less than 4000 tublings over an area of about 3.5 hectares (8.6 acres). Planting began during the last week of February. Precipitation was slightly above normal during the months of February and March but below normal in the month preceding (Fig 2); two days were documented with snow on the ground during the months of February and March (Fig 3). First-year survival was low (26.6 percent ${ }^{1}$ ) across the planting area, most likely due to the late-season planting which left insufficient time for transplant establishment prior to spring warm up and the onset of resource competition. Irrigation was not used.

During the FY08 reporting period, a second planting was organized and carried out. This time, 10 -in ${ }^{3}$ tublings were purchased instead of the smaller $4-\mathrm{in}^{3}$ tublings used previously. The decision to purchase larger transplant stock, while slightly more expensive, was based in part on low survival rates observed on this project and reported by others using $4-\mathrm{in}^{3}$ transplant stock on similar planting sites. Planting began on January 8 with the delivery of 2665 tublings and was completed on January 10. Planting conditions were considered excellent, with adequate moisture and snowy conditions before, during, and after the planting event (Fig 2); 39 days were documented with snow on the ground during the months of January and February 2008 (Fig 3). Irrigation was not used. Survival totaled 73 percent during the first year. Monitoring of the FY07 planting showed 11 percent survival after the second year.

This year, activities included collecting sagebrush seed; making arrangements with a local grower to produce between 2250 and 2500 10-in ${ }^{3}$ tublings; and annual monitoring of the FY07 and FY08 planting transects. Compensatory plantings are monitored annually for 5 years to confirm a customary performance criterion of $60 \%$ survival.

\footnotetext{
${ }^{1}$ Seven transplants, not previously documented or reported, were identified along two monitoring transects (P2-07 and P3-07). Transplant descriptions were added to the data for this planting with resultant changes to both the number of monitored transplants and previously reported survival percentages. Reference values reported in this annual status report supersede those previously reported by Durham and Sackschewsky (2007 and 2008).
} 


\subsection{Methods}

All previously mapped transplants were revisited during the week of June 10 following the methods described by Durham and Sackschewsky (2007) for monitoring the permanent 50-m x 20-m transects established at the time of planting. Measures of transplant height and two widths were recorded. Each transplant was then ranked according to appearance as healthy, marginal, or dead. A transplant was ranked as healthy if its leaves were turgid. Transplants ranked as marginal exhibited 75 percent or more chlorotic foliage or extensive wilting was observed. Transplants were considered dead when no live leaves were present on any stem, or when previously mapped transplants could not be found.

\subsection{Results}

\subsection{Transplant Survival}

FY07 Planting: Third-year survival totaled 10.4 percent across all (3) monitoring transects (Fig 4). This represents a 0.6-percent decrease from the previous monitoring year, and equates to the loss of only one transplant (ranked as marginal in FY08). Of those transplants still living $(n=16)$, all were judged to be in healthy condition in 2009 (Fig 5).

FY08 Planting: Second-year survival totaled 64.5 percent across all (2) monitoring transects (Fig 4); down 8.5-percent from the previous monitoring period. Of those transplants still living ( $\mathrm{n}=129), 97$ percent were judged to be in healthy condition (Fig 5).

\subsection{Transplant Height}

Figure 6 shows the average transplant height measured during each monitoring period, from planting (Time 0) through 2009, for both planting years (FY07 and FY08). Transplant heights averaged $8 \mathrm{~cm}$, regardless of container size, at the time of planting. Tublings planted in FY08 were taller on average during all subsequent monitoring periods. FY07 transplants averaged $19 \mathrm{~cm}$ and FY08 transplants averaged $25 \mathrm{~cm}$ in 2009.

\subsection{Discussion}

To meet the 60-percent survival criterion for mitigation success, 3000 living transplants will need to be established on the site at the end of five monitoring years (FY2014). Currently there is an estimated 2130 surviving sagebrush transplants on the mitigation site (10\% of about 4000 transplants, and $65 \%$ of 2665 transplants). Some additional mortality should be expected. In early FY09, estimates of future survival were used to determine the number of tublings to plant in FY10 to accomplish the mitigation goals for this project. An order was placed with a local grower in April 2009 to produce between 2250 and 2500, 10-in ${ }^{3}$ tublings.

Once established, sagebrush is long-lived, nevertheless true restoration of sagebrush into the landscape will require continual recruitment within a suitable seedbed for sagebrush to persist over the long term. In FY09, seed were collected from a stand of sagebrush within $1 \mathrm{~km}$ of the mitigation site. One reason for choosing seed derived so near the site was to capture the inherited characteristics that have evolved in response to specific local stresses. This may or may not affect the outcome of transplant survival in the near term but successful recruitment on this site may depend upon this choice. Seed production varies greatly between years and between stands due to differences in climate, stand density and maturity, soil and genetics. Research suggests that genetic factors are involved in the timing of germination patterns both among and within the subspecies of sagebrush (Meyer and Monsen 1990). The exact matching of site genetics could provide the building blocks for success. 
Activities for FY10, in addition to annual monitoring and reporting for all planting years, will include laying out the site for an early-winter planting, planting arrangements and field oversight, and time-zero measurements. Steps to increase survival, beyond those stated previously, may include a fertilizer treatment (in pellet form placed into a separate hole near each new transplant), or a modified planting strategy to facilitate water capture.

\subsection{Conclusions}

If the minimum number of tublings grown for planting in FY2010 meets quality specifications, and planting conditions are favorable, conservative survival estimates indicate the habitat mitigation goals outlined in the MAP for Project L-325, Electrical Utility Upgrades (Fluor 2007) will be met in FY2014.

\subsection{References}

Durham, R.E., and M.R. Sackschewsky. 2007. L-325 Sagebrush Habitat Mitigation Project: FY2007 Compensation Area Monitoring Report. PNNL-16975. Pacific Northwest National Laboratory, Richland, WA.

Durham, R.E., and M.R. Sackschewsky. 2008. L-325 Sagebrush Habitat Mitigation Project: FY2008 Compensation Area Monitoring Report. PNNL-17926. Pacific Northwest National Laboratory, Richland, WA.

Fluor Daniels Hanford Co (Fluor) 2007. Mitigation Action Plan for Project L-325, Electrical Utility Upgrades. Fluor Daniels Hanford Co., Richland, WA. HNF-31621.

Hanford Meteorological Station website. Accessed on 9-20-2009, at http://hms.pnl.gov/products/

Meyer, S. E., and S. B. Monsen. 1990. Seed-source differences in initial establishment for big sagebrush and rubber rabbitbrush. in E. D. McArthur, E. M. Romney, S. D. Smith, and P. T. Tueller, editors. Proceeding-Symposium on cheatgrass invasion, shrub die-off, and other aspects of shrub biology and management. USDA Forest Service Intermountain Research Station General Technical Report: INT-276:200-208.

U.S. Department of Energy. 2001. Hanford Site Biological Resource Management Plan. DOE/RL 9632 Rev. 0. U.S. Department of Energy, Richland, WA.

U.S. Department of Energy. 2003. Hanford Site Biological Resource Mitigation Strategy. DOE/RL 9688 Rev. 0. U.S. Department of Energy, Richland, WA. 


\subsection{Figures}
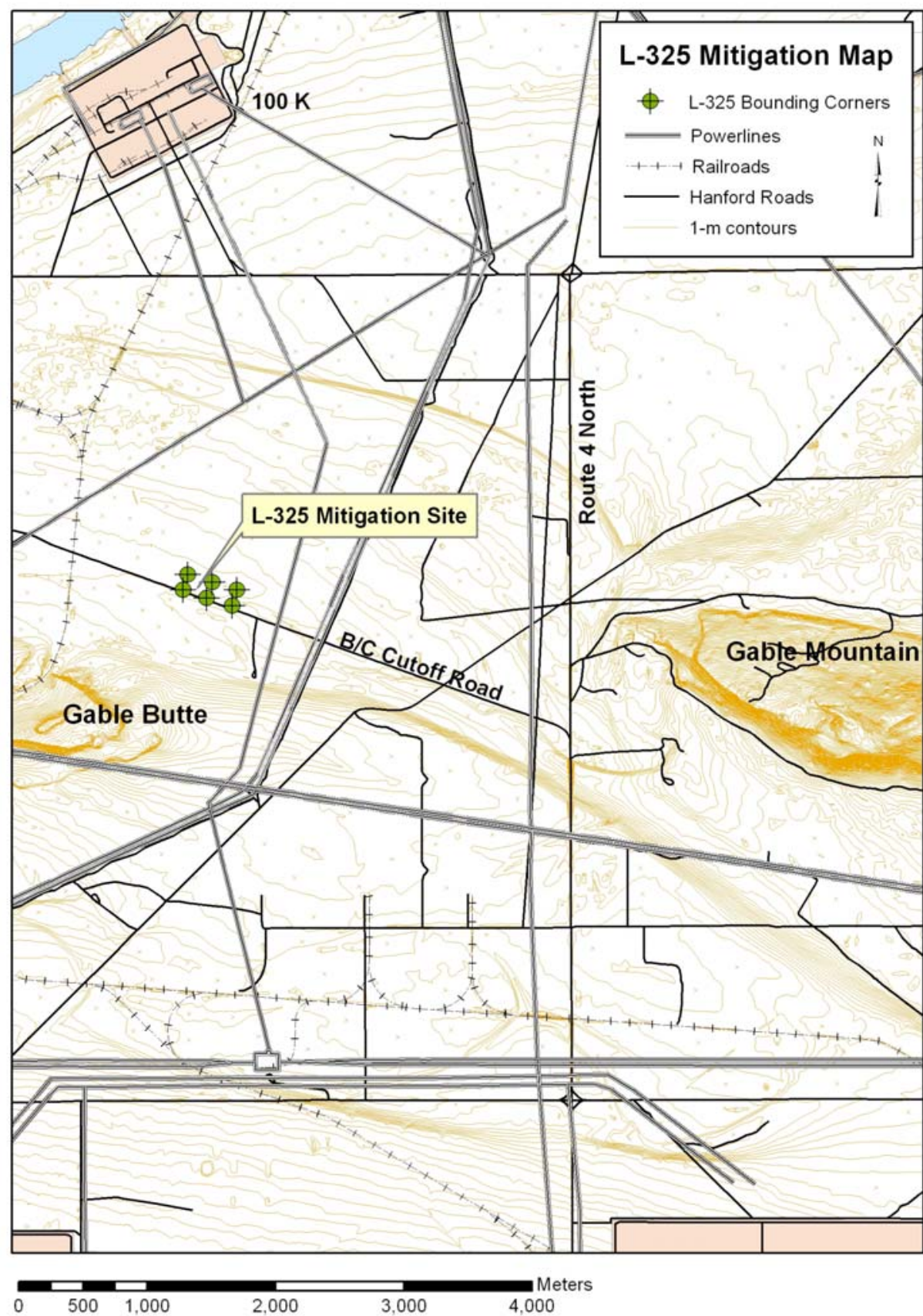

Figure 1. Location of the L-325 Compensatory Mitigation Site in Relation to the B/C Cutoff Road and Gable Butte 


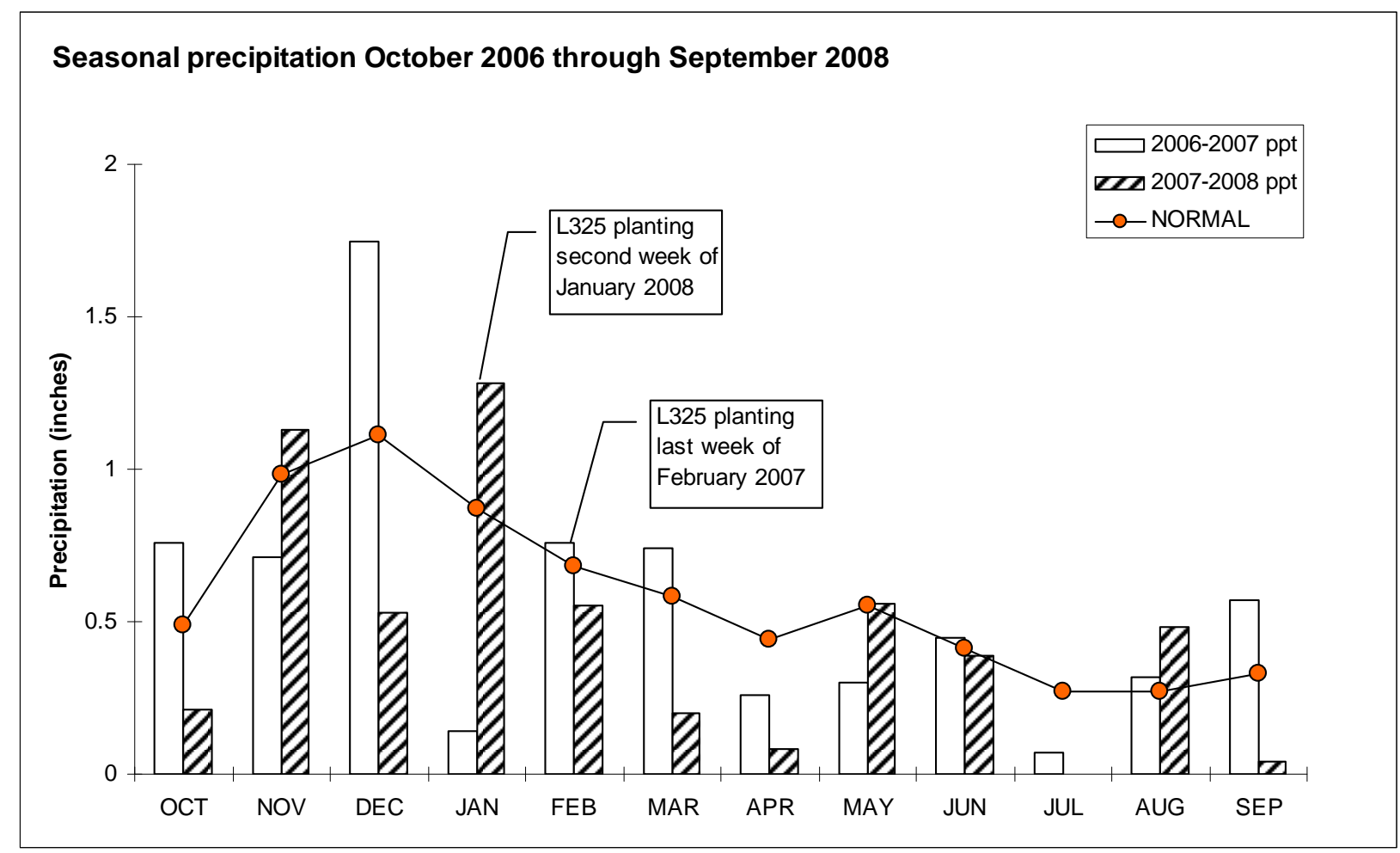

Figure 2. Seasonal Precipitation (Adapted from Table 4.1 on the Hanford Meteorological Station Webpage, http://hms.pnl.gov/totprcp.htm)

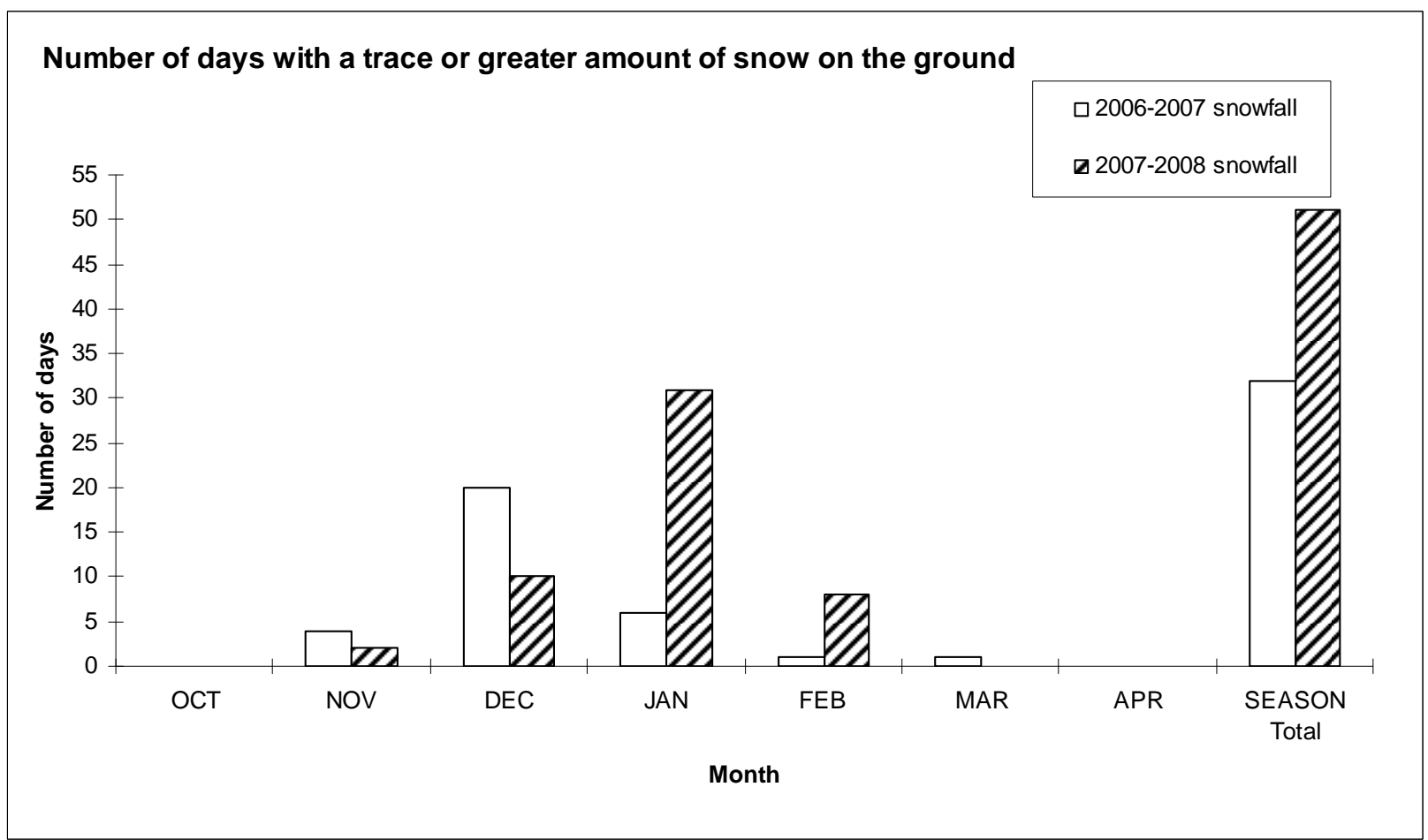

Figure 3. Days with a Trace or Greater Amount of Snow on the Ground at $0400 \mathrm{hr}$ at the Hanford Meteorological Station (Data were Obtained from Monthly Summary Tables for Calendar Years 2006, 2007, and 2008 at http://hms.pnl.gov/products/) 


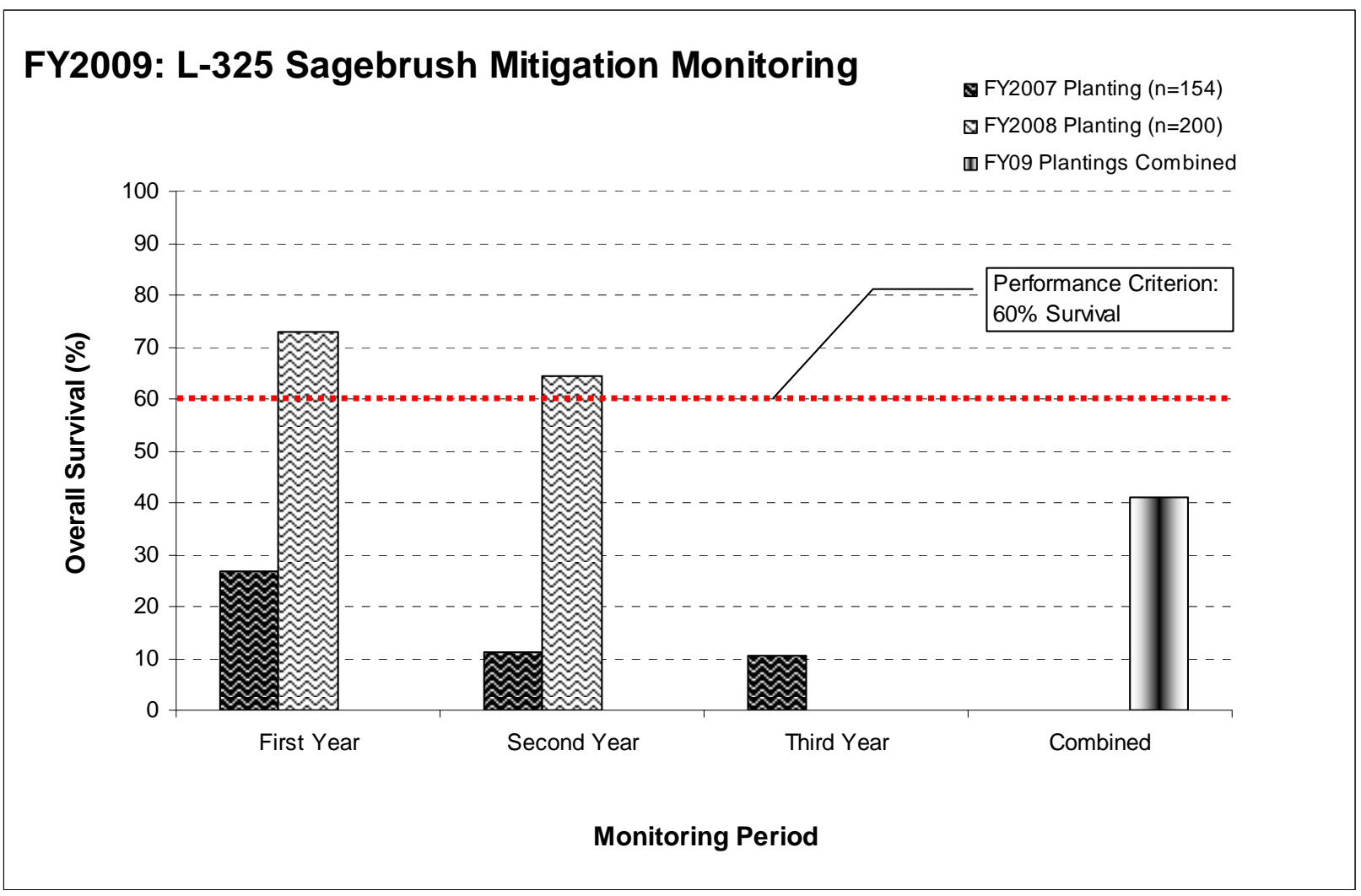

Figure 4. Overall Survival by Planting Year and Monitoring Period (Combined Survival is Based on $\mathrm{n}=354$ Transplants from Both Planting Years) 


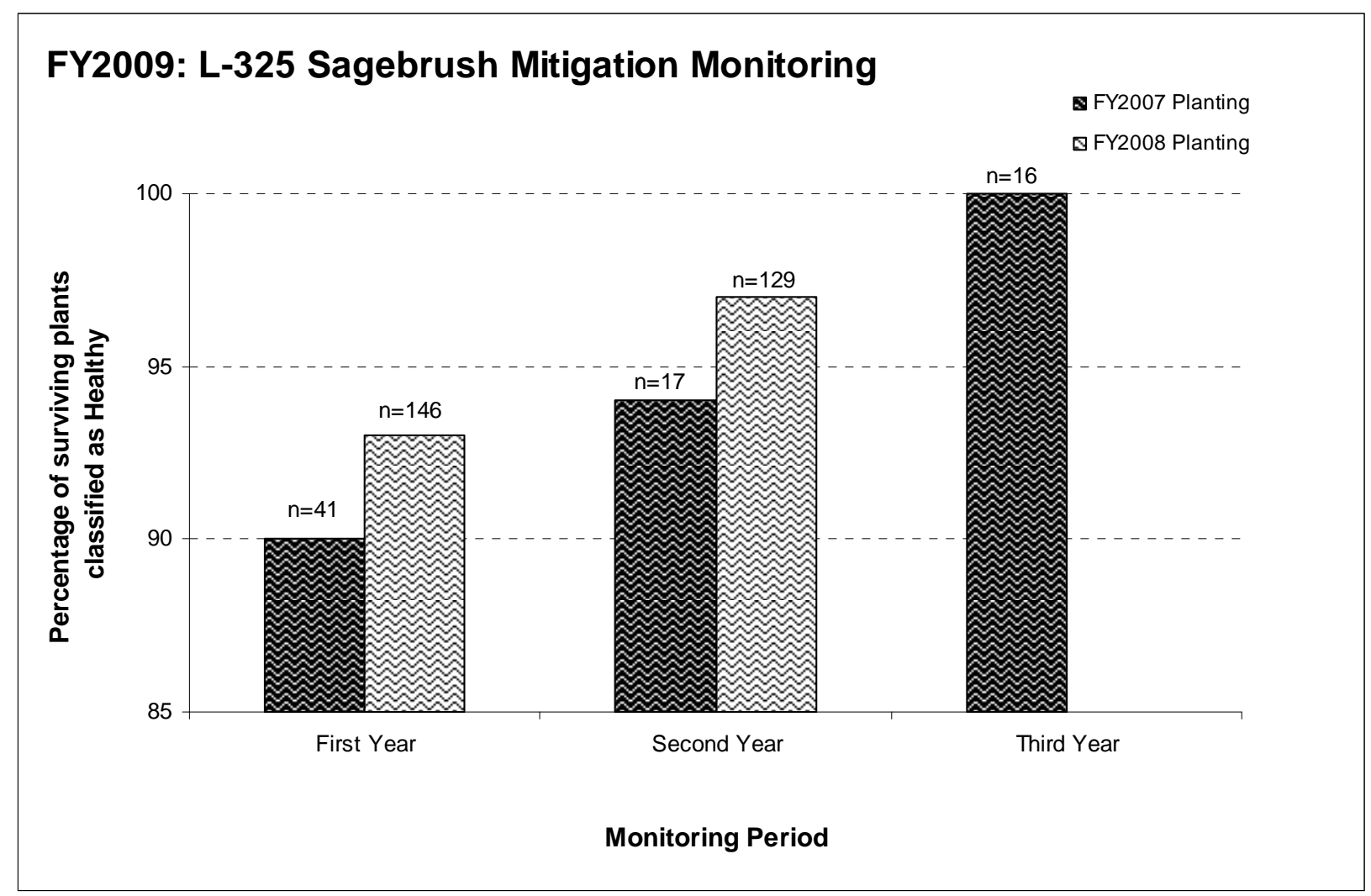

Figure 5. Percentage of Surviving Transplants Ranked as Healthy in 2009 


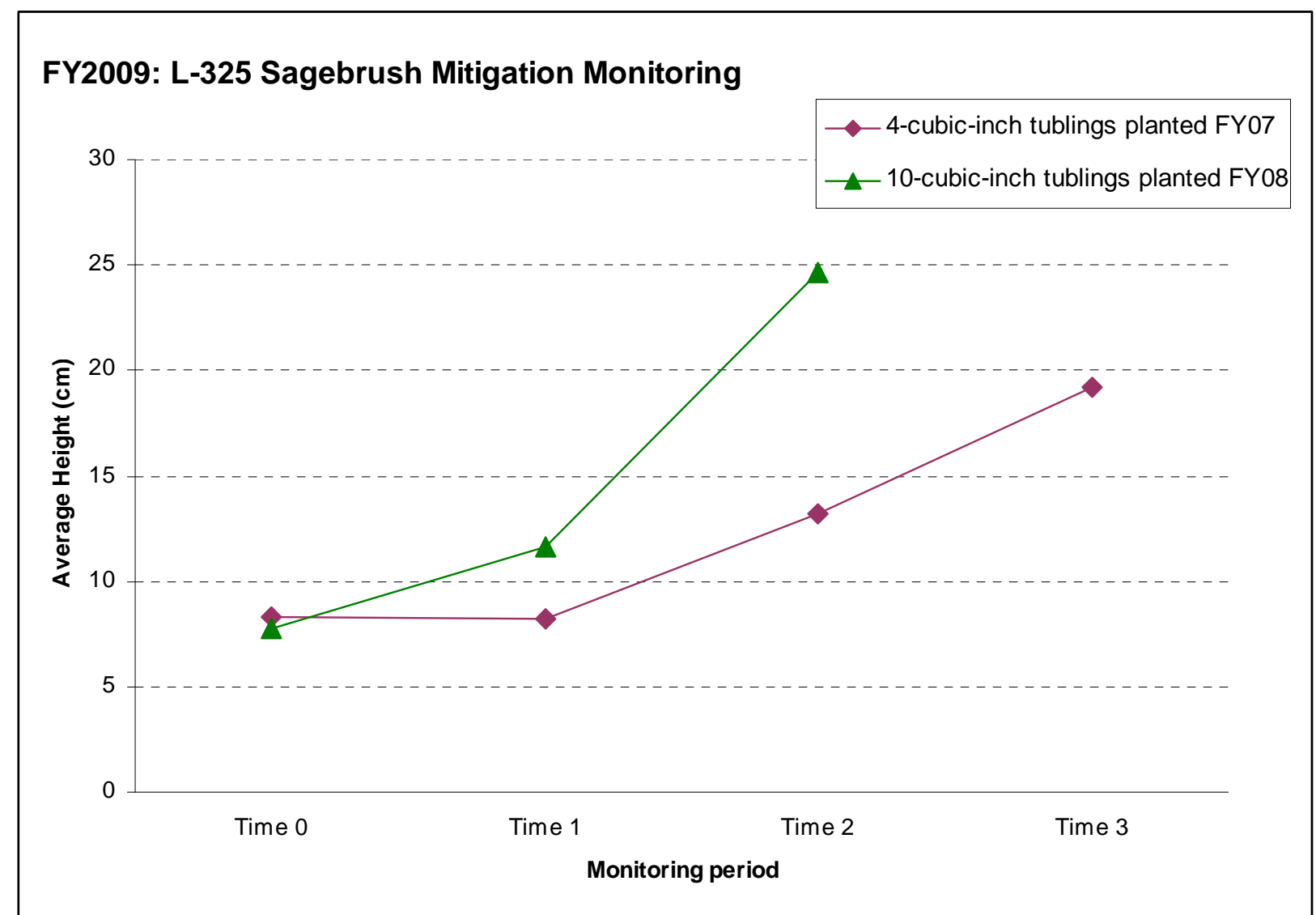

Figure 6. Average Transplant Height Measured at Planting (Time 0) and at Subsequent Annual Monitoring Events 